\title{
Duodenum and Ampulla of Vater Neuroendocrine Tumor pN1 TNM Finding v8
}

National Cancer Institute

\section{Source}

National Cancer Institute. Duodenum and Ampulla of Vater Neuroendocrine Tumor pN1

TNM Finding v8. NCI Thesaurus. Code C135074.

Duodenum and ampulla of Vater neuroendocrine tumor with regional lymph node involvement. (from AJCC 8th Ed.) 